\title{
CONTRIBUTIONS ON THE MINERALOGY OF THE CORUND CARBONATE DEPOSIT
}

\author{
TÓTH ATTILA ${ }^{1}$
}

\begin{abstract}
The carbonate deposit with aragonitic aspect from Corund (Harghita county) is the result of post-volcanic phenomena, and it is deposited from salty bicarbonatic springs. Mineralogically it consists of calcite, magnesium calcite and aragonite. Most of the calcite layers are in fact paramorphoses after aragonite, fact revealed by the diagenetic processes.
\end{abstract}

Keywords. Postvolcanic accumulation of aragonite and calcite, Corund, Harghita country

\section{Introduction}

Though it is the metastable polymorph of calcite at high temperature and pressure, aragonite can form, when certain conditions are met, at normal pressure and temperature. According to the $\mathrm{Ca}-\mathrm{Mg}-\mathrm{C}-\mathrm{O}-\mathrm{H}$ state diagram, aragonite deposition is mainly favoured by the $\mathrm{Ca} / \mathrm{Mg}$ ratio and the concentration of $\mathrm{CO}_{2}$ from solution (fig. 1). Fischbeck and Müller (1971) have shown that, at a ratio of $2.9 \mathrm{Mg} / \mathrm{Ca}$, aragonite is the main calcium carbonate that forms, while at a ratio of 4.4 is the only one. Filipov (1990) established that at a temperature of $10^{\circ} \mathrm{C}$ and $\mathrm{a} \mathrm{pH}=7$, aragonite forms when the $\mathrm{Mg} / \mathrm{Ca}$ ratio reaches 0.4 . Aragonite precipitation is also influenced by other ions, such as $\mathrm{Na}^{+}$and $\mathrm{SO}_{4}{ }^{2-}$. Thus, at a variation of the concentrations of $\mathrm{Mg}^{2+}$ and $\mathrm{Na}^{+}$ions (from hypersaline to normal marine), magnesium calcite and aragonite crystals grow fastly in the direction of the c axis, and very slowly in the direction of the other axes (Lippmann, 1960). $\mathrm{SO}_{4}{ }^{2-}$ and $\mathrm{Mg}^{2+}$ ions inhibit the development of calcite crystals and determine crystal growth parallel with the c axis (Bischoff and Fyfe, 1969).

Our paper proposes to clarify the mineralogenetic processes that resulted in the carbonate accumulation from Corund. The aspect of the carbonate deposit is aragonitic, but mineralogically it consists of calcite, magnesium calcite and aragonite. The unsolved problem is the origin of calcite: whether it was deposited primarily or resulted through subsequent recrystallisation processes.

${ }^{1}$ Dept. of Mineralogy, Faculty of Biology and Geology "Babeș-Bolyai" University, Kogă Iniceanu, 1, 3400 Cluj-Napoca, Romania. 


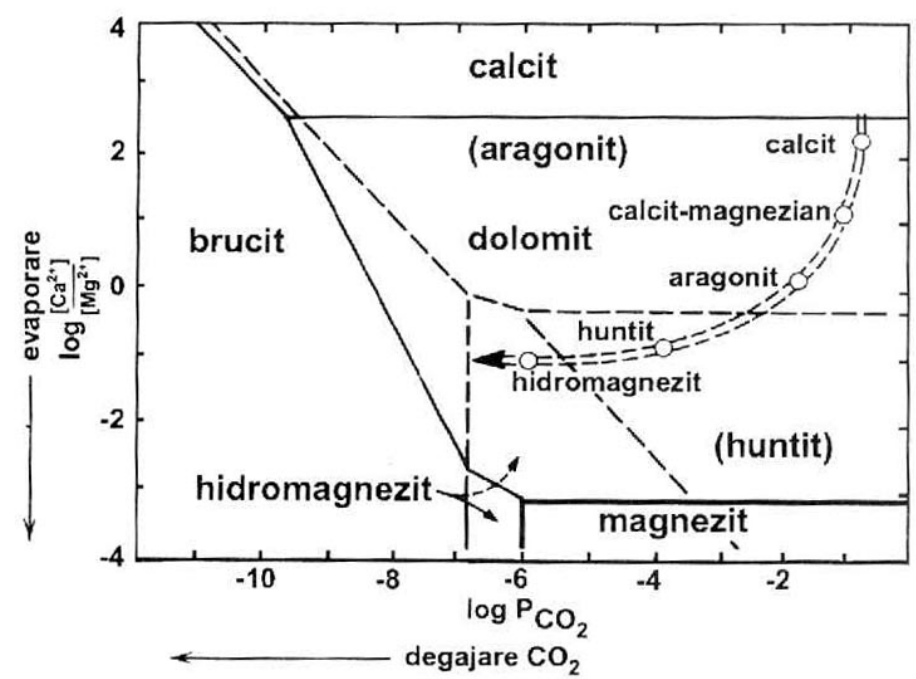

Fig. 1. The evolution of cave water with respect to increasing evaporation and carbon dioxide loss (after Lippmann, 1973)

\section{Location}

The carbonate accumulations are situated in the eastern part of the Transylvanian Basin, on the territory of Corund commune (Harghita county) (fig. 2). Carbonates, in the shape of three hillocks, outcrop north from Corund, in the right slope of Corund Valley, at an altitude of $540 \mathrm{~m}$, along the road Praid-Corund, and have an extension of about $1000 \mathrm{~m}$. The outcrops are developed perpendicular on the valley, respectively on the tectonic axis of the diapiric folds and have a quasi-vertical position (Gheorghiu et al., 1962).

\section{Geologic context and previous research}

Geological formations from the area are represented by the products of Neogene volcanic activity from the Gurghiu massif (andesitic agglomerates and lava flows) and by Pannonian sedimentary rocks (salty clays, limy clays, sandstones) with intercalations of volcanic tuffs and volcanoclastic agglomerates. The Miocene salt diapiric structure from Praid is located north from the carbonate deposits.

The first paper to mention the carbonate accumulations from Corund belongs to Koch (1884-1885). Based on this information, Vencel, in 1908, requests an authorization to quarry the deposits. The first blocks, extracted in 1910, were processed at the School of Arts and Crafts from Zlatna. The polishing workshop from Corund was built in 1916 and so began the main phase of rock exploitation. The flourishing period of exploitation and processing of Corund carbonate rocks is recorded in the interval 1930-1939 (Gheorghiu et al., 1962). 150 


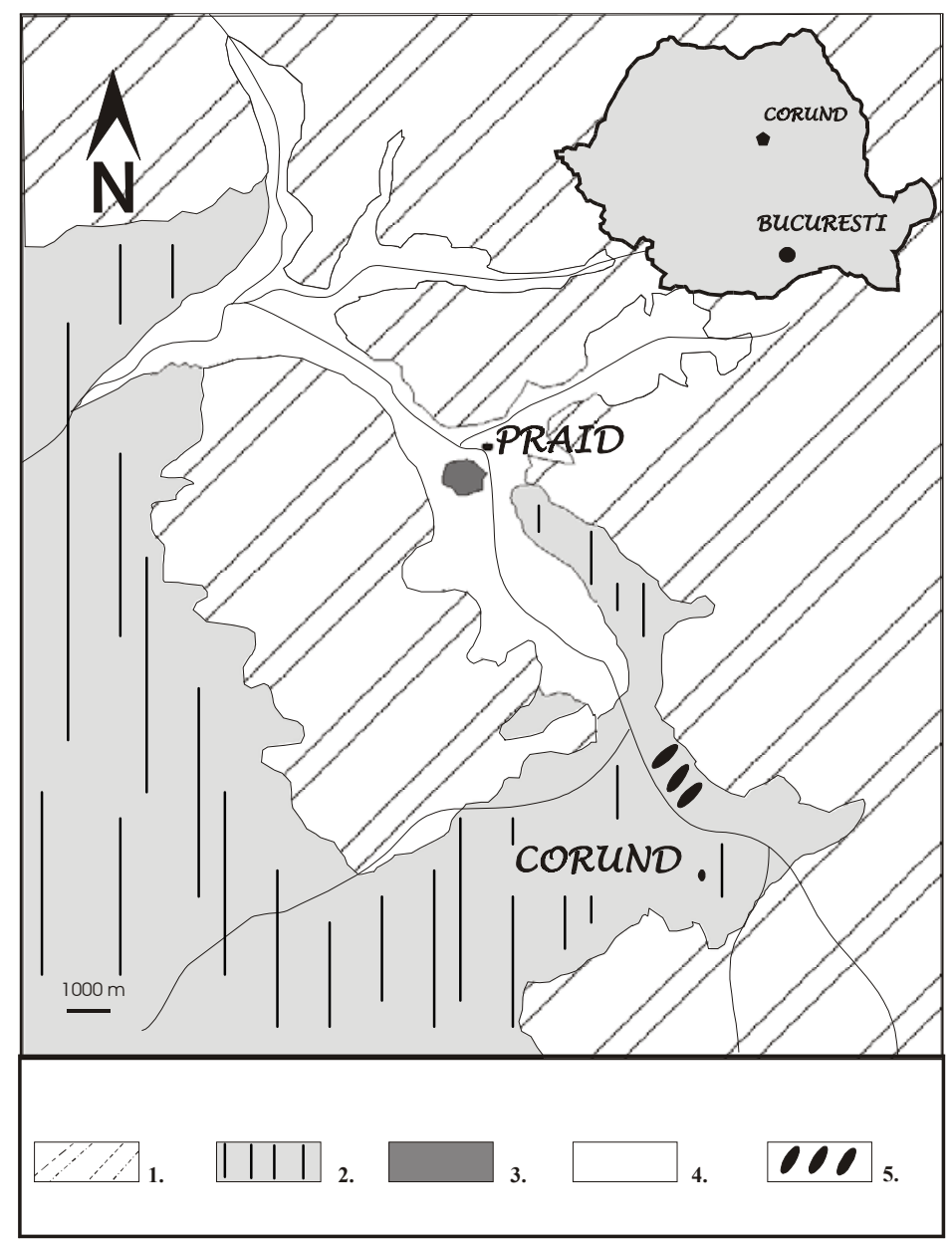

Fig. 2. The location of the investigated site. 1. Andesitic agglomerates and lava flows;

2. Pannonian sediments; 3. Miocene salt diapire; 4. Quaternary sediments; 5. Carbonate deposits.

One main interest of the previous studies is the mineralogy of the accumulations. Koch (1949) uses the term of "aragonite from Corund". Vendl (1929) and Vendl (1942) deny the presence of aragonite, while Metta (19271928), based on colour analyses (Meigen reaction), states that the deposit consists of calcite, not of aragonite. Gliszczynski and Stoicovici (1937), based on the fluorescence and phosphorescence properties, consider that the rock consists of calcite and the phosphorescence is due to rare earth elements. Gheorghiu et al. (1962) report the presence of both calcite and aragonite, mostly based on colour reactions; their paper also makes a detailed description of the rock textures and presents a series of qualitative spectral analyses. 


\section{Analysis methods}

The samples taken were studied both macro- and microscopically (transmission polarizing microscope - Jenapol and stereomicroscope), by X-ray diffractometry (Dron $3, \mathrm{Cu}_{\lambda} \mathrm{K}_{\alpha}=1,54051 \AA$ ) and by chemical analyses (ICP-AES) at I.C.I.A. Cluj - Napoca.

\section{Macroscopic aspects}

The carbonate deposits have an "ore" aspect because they represent the fillings of fractures crossing the sedimentary deposits (volcanoclastic agglomerates, marls, clays and sandstones) and were formed by precipitation from mineralized springs, process that continues at present. Several depositional phases may be separated, closely connected to the composition, concentration and the flowrate of solutions, respectively to their circulation path.

Crystals develop perpendicular on the deposition surface, which may be smooth, more or less wavy, or may present various irregularities formed especially by local crystallization of carbonates around tiny voids circulated by solutions. Crystal habit is prismatic or fibrous with a quasi-parallel or fan (funneltype) orientation when they have as support granoclasts (xenoclasts or agglomerations of carbonate crystals). The fabric is prismatic or fibrous, generally banded due to the inclusion, at several levels (corresponding to certain stages of deposition) of impurities consisting of clay minerals, iron or manganese oxyhydroxides, iron sulphides and organic substances. Gheorghiu et al. (1962) describes in detail 8 types of bandings. We could also notice vacuolar structures determined by water circulation and gas emanations $\left(\mathrm{CO}_{2}\right)$.

The water that deposits the carbonates has a high salt and $\mathrm{CO}_{2}$ concentration and appears at surface under pressure. Physico-chemical data recorded on the spring from the northern part of hillock 1 show a weak acid $\mathrm{pH}$ $(\mathrm{pH}=6,5)$, low temperature $\left(8,5^{\circ} \mathrm{C}\right)$ and a negative redox potential $\left(\mathrm{Eh}_{\mathrm{Ag} / \mathrm{AgCl}}\right.$ : $20 \mathrm{mV}$ at $\left.\mathrm{t}=8,5^{\circ} \mathrm{C}\right)$, indicating a strongly reducing environment.

\section{Microscopy}

Microscopic observations were done on thin sections parallel and perpendicular on crystal elongation. In sections parallel to the elongation we could distinguish at least three distinct types:

a) crystals with prismatic habit elongated after the $c$ axis (parallel extinction), oriented parallel, with rare deviations which meet in high angle limits (Plate I, fig. 1). These crystals have a cleavage parallel with the elongation after the face (010), characteristic to aragonite, and in perpendicular sections we could distinguish cyclic and alternating twinning (Plate I, fig. 2). At several levels the crystals have inclusions of colored minerals (manganese oxide dendritic crystals, organic substances, clay minerals), giving a banded structure. Sometimes there appear thicker browny bands formed by iron oxy-hydroxides (goethite, fig. 3, Plate III, fig. 5, 6) in which we could distinguish opaque grains which sometimes have iron sulphide relics in the center. The presence of iron sulphide deposits attests the reducing environment of the mineralizing solutions. 
b) fibrous crystals grown in fan (funnel-type) which have as a starting point crystallization germs formed at a certain distance from one another. Crystals developed at an angle less than 90' from the surface (radial growth) are joined after irregular contacts. This structural type may have been crystallized from an amorphous mass of calcium carbonate (Plate II, fig. 3, 4).

c) rhombohedral or scalenohedral calcite crystals which normally grow on the walls of voids (Plate IV, fig. 7).

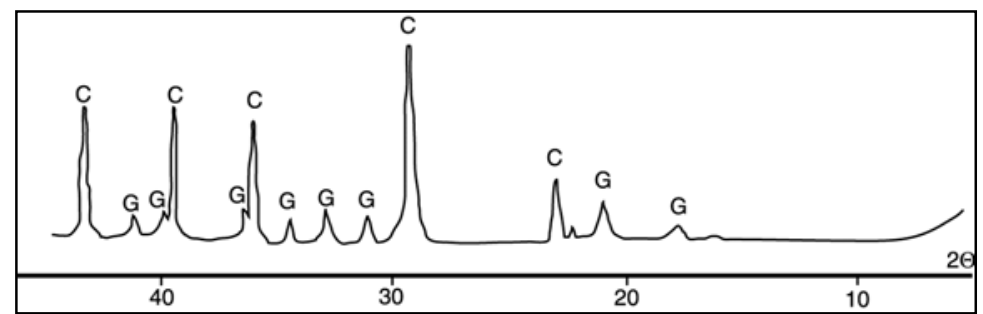

Fig. 3. Diffraction spectra of goethite and calcite.

\section{X-ray diffractometry}

X-ray diffraction analyses were done on various levels with respect to the aragonite level which we determined at the microscope (fig. 4) XRD analyses confirmed the aragonite level interspersed between two levels of magnesium calcite, having at its base a magnesian calcite only level and at the top a mixture of magnesium calcite with $10 \%$ aragonite which underwent recrystallization (paramorphosis). The presence of the two minerals in the mixture attests the paramorphosis of magnesium calcite after aragonite. The aragonite content of the recrystallized deposits depends on the degree of transformation.

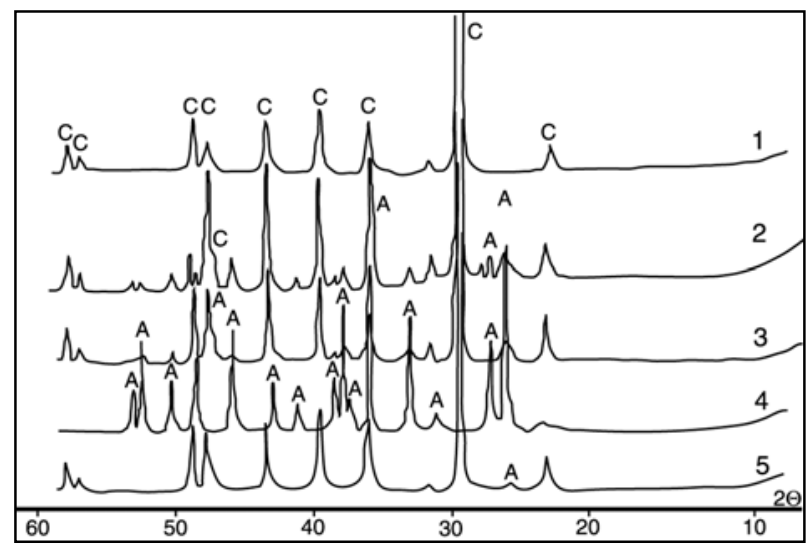

Fig. 4. Diffraction spectra of aragonite and magnesium calcite: 1, magnesium calcite; 2 , actual deposit; 3 , level at the upper part of aragonite; 4, aragonite; 5, level at the base of aragonite. 
Alternances of magnesium calcite and aragonite appear in the most recent crusts. Magnesium calcite from the top of the crusts is easy to be recognized from its rhombohedral habit.

\section{Chemical analyzes}

Taking into account the role of the magnesium ion in the calcite-magnesium calcite-aragonite system, we have done chemical analyzes on several carbonate levels and on the spring water. The magnesium content is high in the water and about half of this value in the actual deposit and in the calcite level from the base of the aragonite. The lowest amount is in the aragonite level (table 1).

Table 1.

Magnesium content of different carbonate sediments and of the spring.

\begin{tabular}{|c|c|c|c|c|}
\hline Aragonite & $\begin{array}{c}\text { Level at base of } \\
\text { aragonite }\end{array}$ & $\begin{array}{c}\text { Level at the upper } \\
\text { part of aragonite }\end{array}$ & Actual deposit & Spring water \\
\hline $220 \mathrm{ppm}$ & $6162 \mathrm{ppm}$ & $5908 \mathrm{ppm}$ & $6691 \mathrm{ppm}$ & $13028 \mathrm{ppm}$ \\
\hline
\end{tabular}

\section{Aragonite paramorphosis}

A part of the aragonite crystals were transformed in calcite, process favored by the circulation of solutions through the pores of the rock after aragonite crystallization. Recrystallization phenomena are marked by the removal of colored inclusions (oxides, hydroxides etc.) from areas circulated by water and the formation of secondary inclusions on the cleavage lines of aragonite, by the local uniformization of banding (visible in the vicinity of microfissures) and by the formation of cleavage characteristic for calcite keeping the orientation of the c crystallographic axis, as well as the appearance of calcite microcrystals with a different orientation. Another observation which attests the calcite paramorphosis after aragonite is the limit of alternating twinnings of aragonite (observable in sections perpendicular on the elongation), sometimes dimmed or missing (Plate IV, fig. 8). If the process is advanced, the twinned structure is replaced by a microgranular one.

Calcite masses may be represented both by fibrous magnesium calcite and by magnesium calcite paramorphoses after aragonite.

\section{Conclusions}

The carbonate deposit with aragonitic aspect is the result of postvolcanic phenomena, being deposited from salty bicarbonated springs. The banding of the deposits is determined by flowrate variations and by the concentration of impurities in solution; the impurities did not inhibit continuous crystal growth. Among the impurities incorporated during carbonate deposition, we mention:

- Manganese oxide dendrites forming dark-colored bands. They were formed by bivalent manganese oxidation in contact with air; 


\section{CONTRIBUTIONS ON THE MINERALOGY OF THE CORUND CARBONATE DEPOSIT}

- Brown iron oxy-hydroxide bands. The presence of thin intercalations of iron sulphides that were later oxidized shows the reducing environment.

The carbonate deposit from Corund consists of magnesium calcite and aragonite. The magnesian calcite or aragonite levels were precipitated depending on the flowrate and the concentration of the solutions. The total amount of magnesium calcite increased in time due to recrystallization phenomena, under the action of solutions circulating on fissures and cleavage planes.

\section{Acknowledgements}

I thank Prof. Dr. Lucret ia Ghergari, Prof. Dr. Corina lonescu, Prof. Dr. B.P. Onac for their invaluable help and patience and Dr. Ana-Maria Rusu for the chemical analyzes.

\section{REFERENCES}

Filipov, A., F. (1990), Formations conditions of aragonite in some caves from Pestera karst region, W. Rhodopes. Ann. Sofia Univ., Geol. Geogr., v. 79, no. 1, p. 162 173. In Bulgarian.

Fischbeck, R., Müller, G. (1971), Monohidrocalcite, hydromagnesite, nesquehonite, dolomite, aragonite and calcite in speleotems of the Frankische Schweiz, Western Germany. Contrib. Min. Petrol., v. 33, p. 87-92.

Gheorghiu, C., Peltz, S., Peltz, M., Mareș, I., M. (1962), Acumulă rile de carbonaț i de la Corund. Comun. Soc. Științ . Nat. Geogr. Geol., vol.III, p. 124-146, București.

Gliszcynski, S., Stoicovici, E. (1937), Fluoreszenz und Phosphoreszenzersheinungen an aragonitartigen Calciten von Corund (Rumänien). Z. Krist. (A), XCVIII, P. 344-350.

Hill, C. A., Forti, P. (1997), Cave minerals of the world, second edition, National Speleological Society, Huntsville, AB., p.75, 143, 145, 237-238.

Koch, A. (1885), Kritische Durchsicht der Mineralien Siebenbürgens. Kolozsvár (Cluj).

Koch, S. (1949), A lévai [Levice Czechoszlovákia] és korondi [Corund, Romania] foráskövek. Acta Min. Petr, (Sci. Natur.) Hung., III, p. 17-29, 6 f., Budapest.

Lippmann, F. (1973), Sedimentary carbonate minerals. Springer Verlag Berlin, p. 230.

Metta, N. (1927-1928), Câteva observațiunii la analiza unui exemplar negru de carbonat de calciu de Corund (Ardeal). D. d. S. ale Șed. Inst. Geol. Rom. Vol. XVI, p. 36-40, 1930, București.

Vendl, M. (1929), Die tehnic wichtigen Mineralsschatze Ungarns. Sopron.

Zepharovich (1873), Mineralogisches Lexicon III, Bd., p. 23, Bad Korund, Wien. 
TÓTH ATTILA

\section{PLATE I}

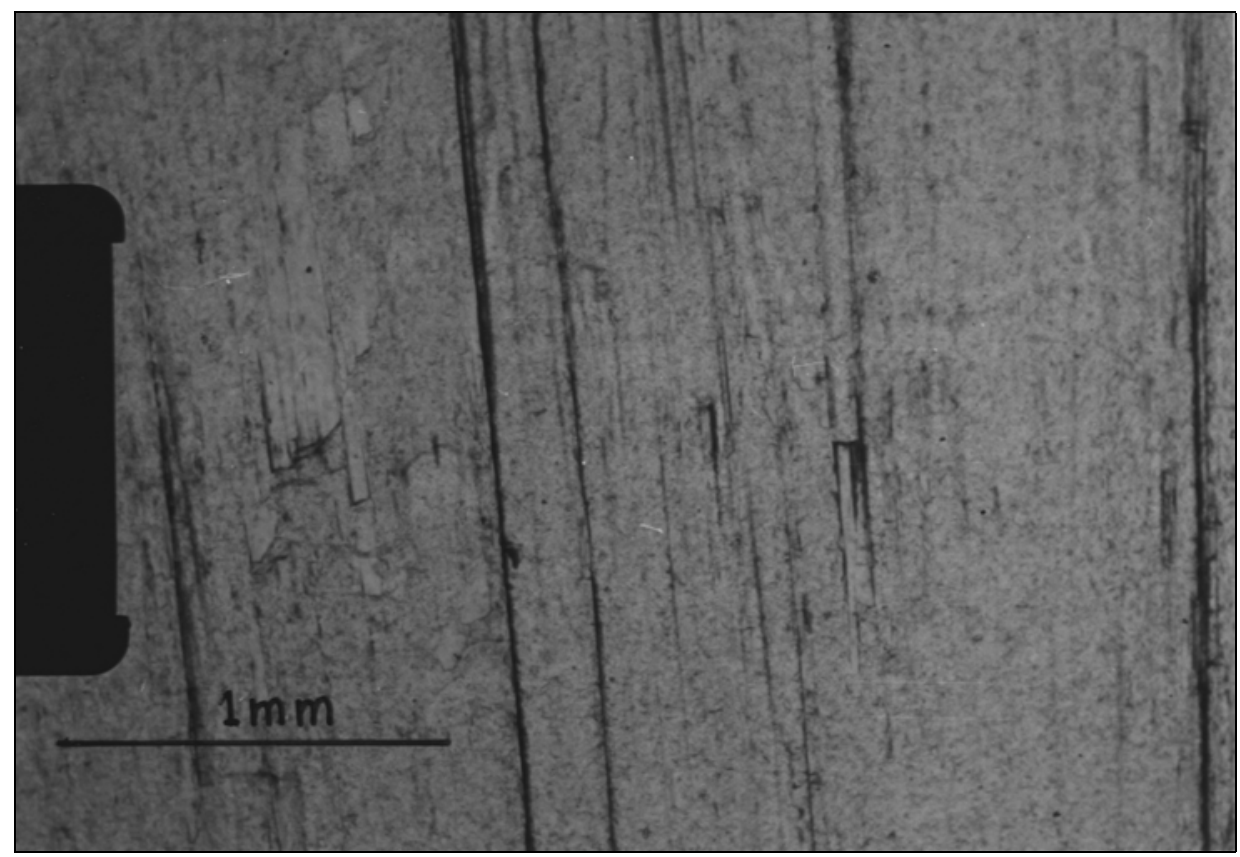

Fig. 1. Aragonite crystals. Thin section parallel with c. $1 \mathrm{~N}, \mathrm{x} 40$.

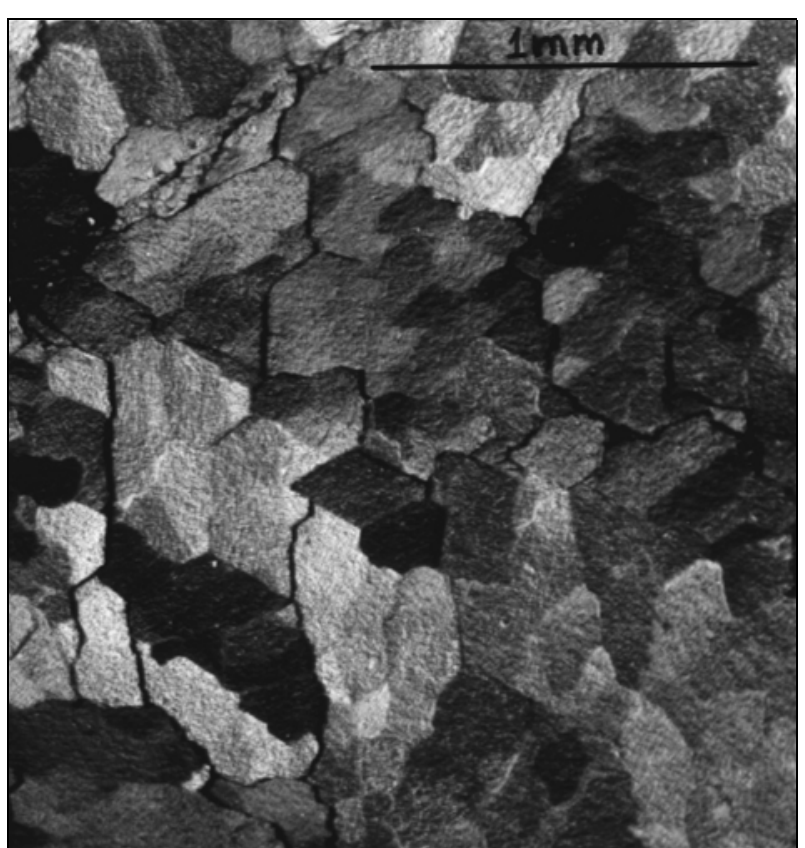

Fig. 2. Cycling and alternanting aragonite twinnings. $\mathrm{N}+, \mathrm{x} 40$. 


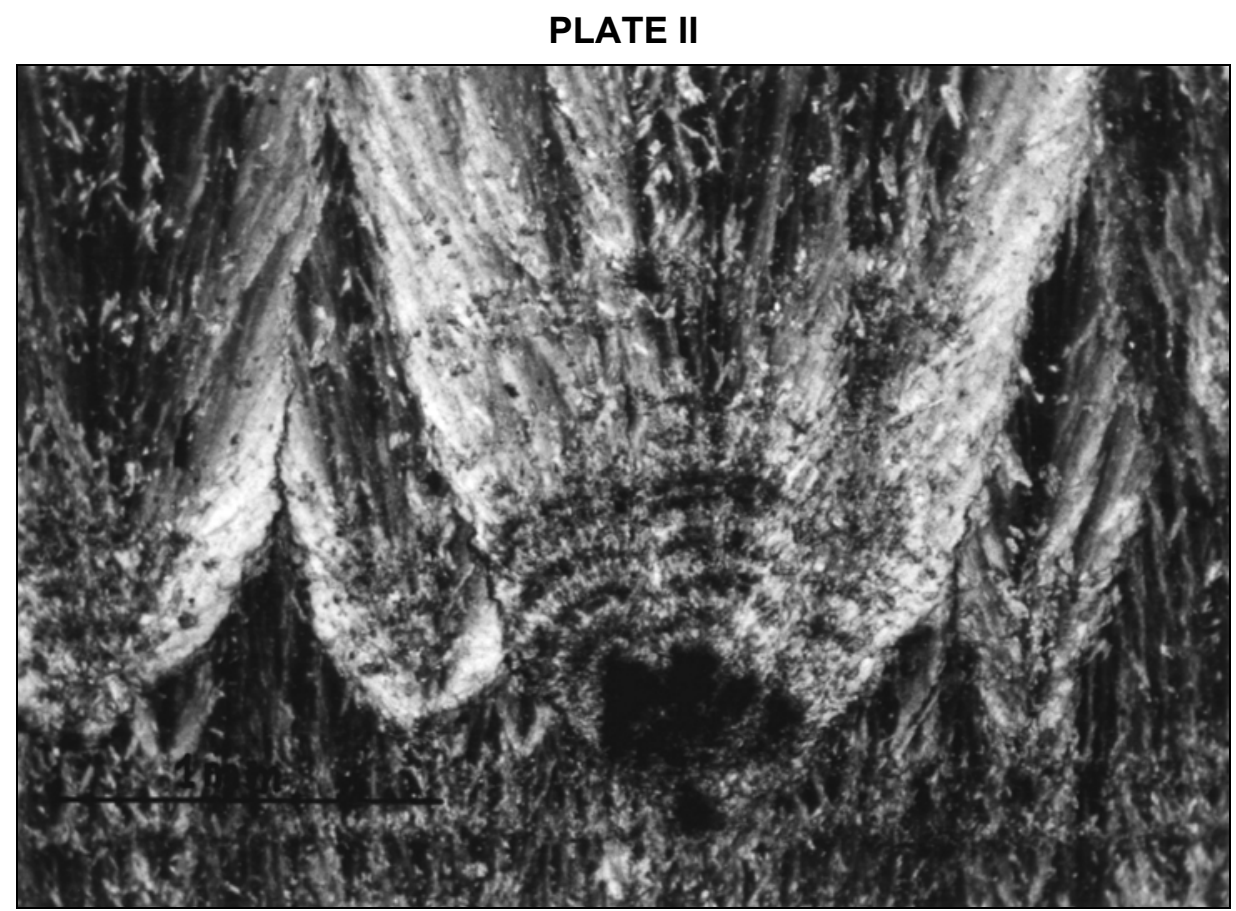

Fig. 3. Growth centers and parabolic fabric of the fibrous calcite $\mathrm{N}+, \mathrm{x} 40$.

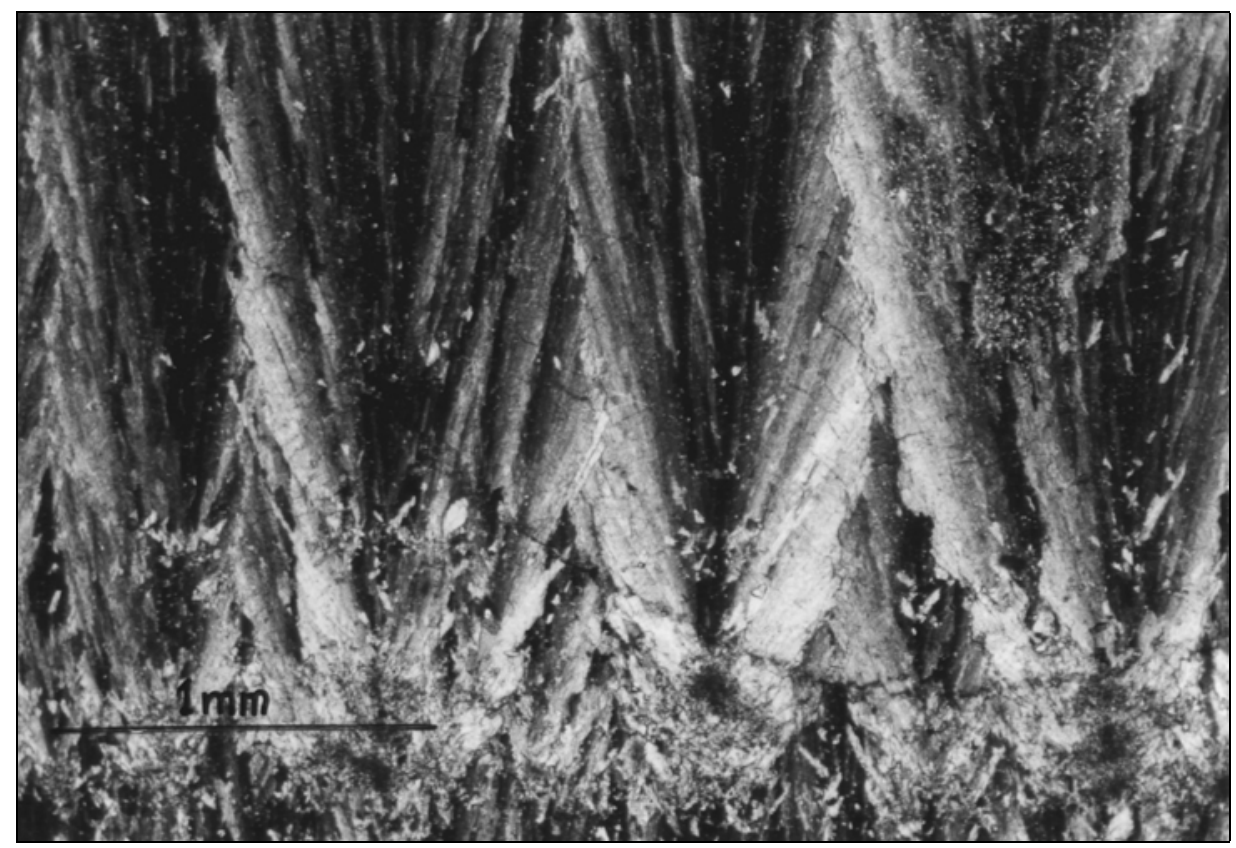

Fig. 4. Calcite fibrous crystals, $+\mathrm{N}$ (x 40). 
TÓTH ATTILA

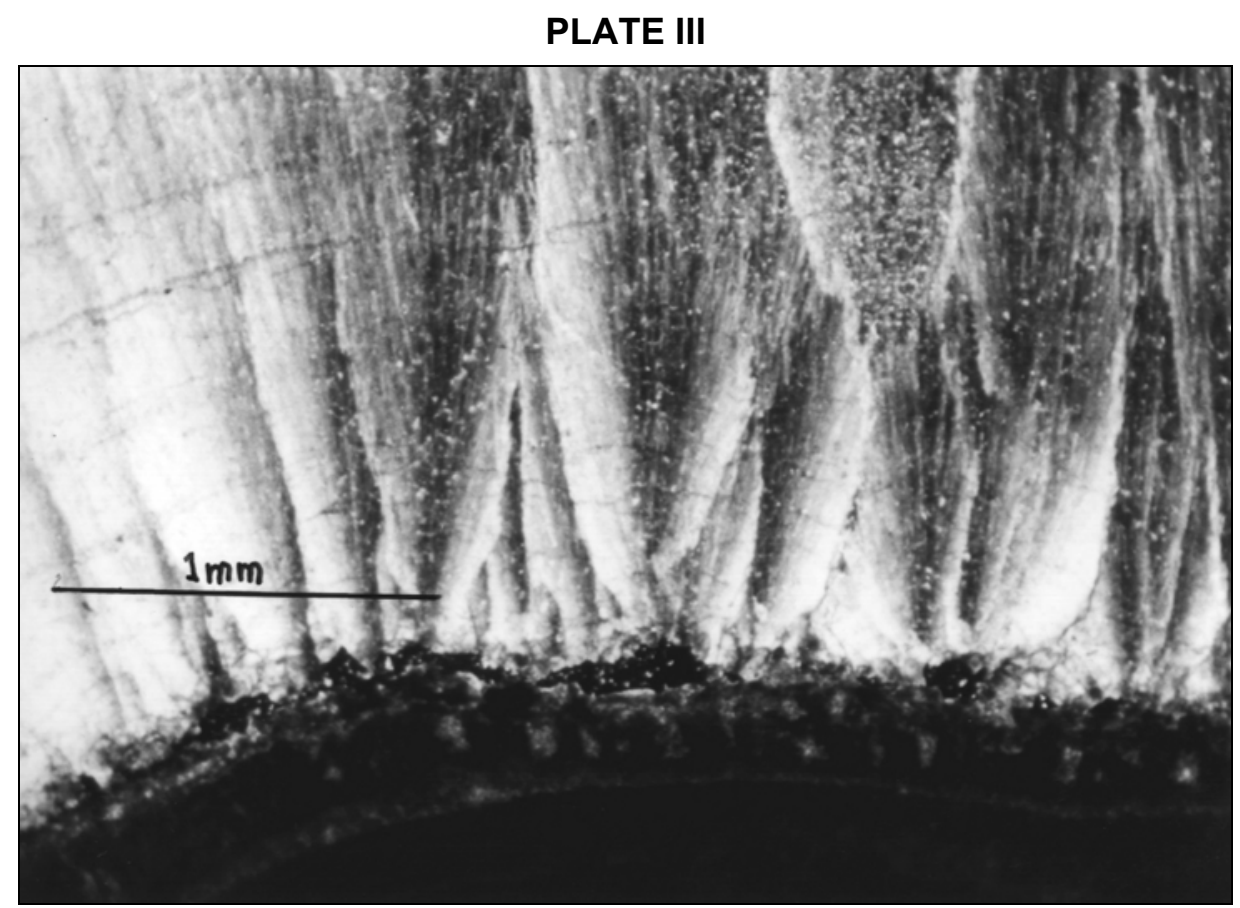

Fig. 5. Fibrous calcite nucleated on goethite layers. $\mathrm{N}+, \mathrm{x} 40$.

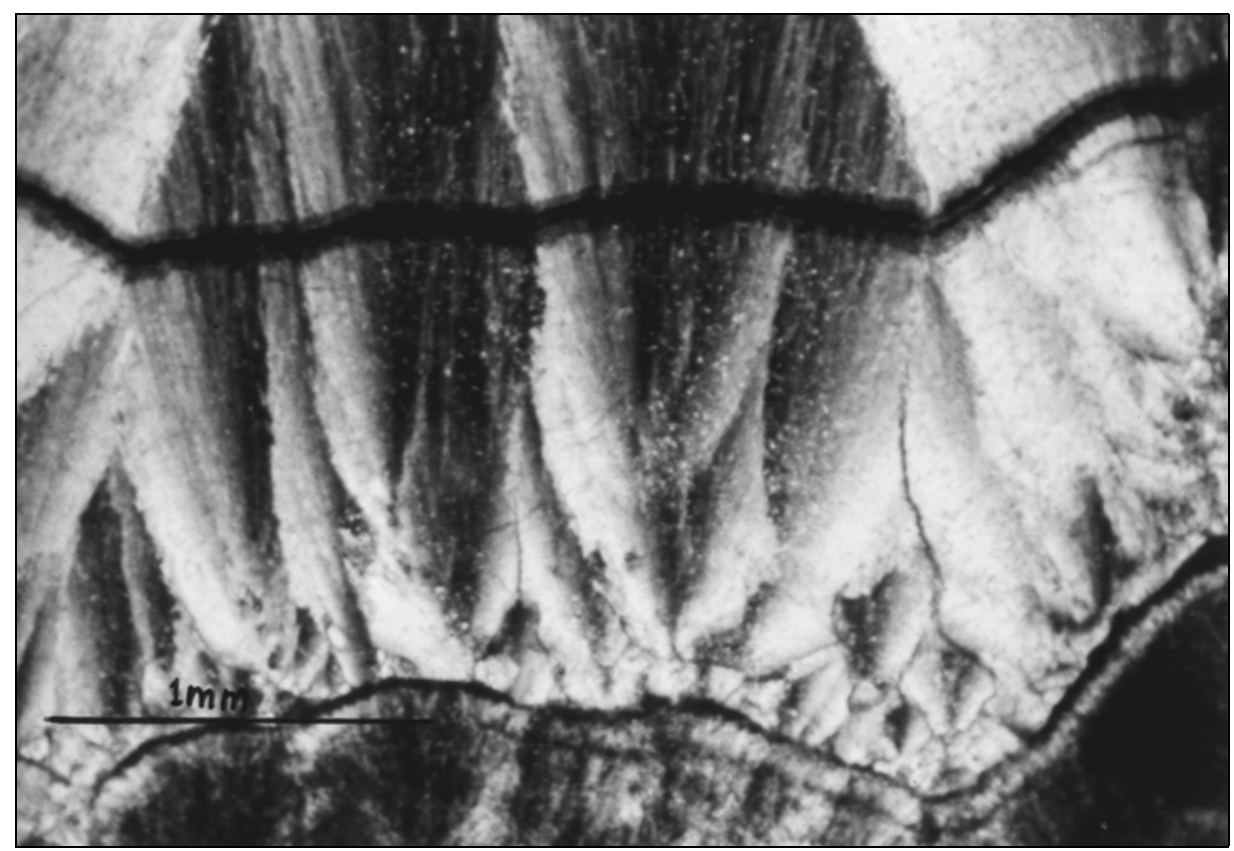

Fig. 6. Fine layers of goethite, cut-crossing fibrous calcite. $\mathrm{N}+, \mathrm{x} 40$. 


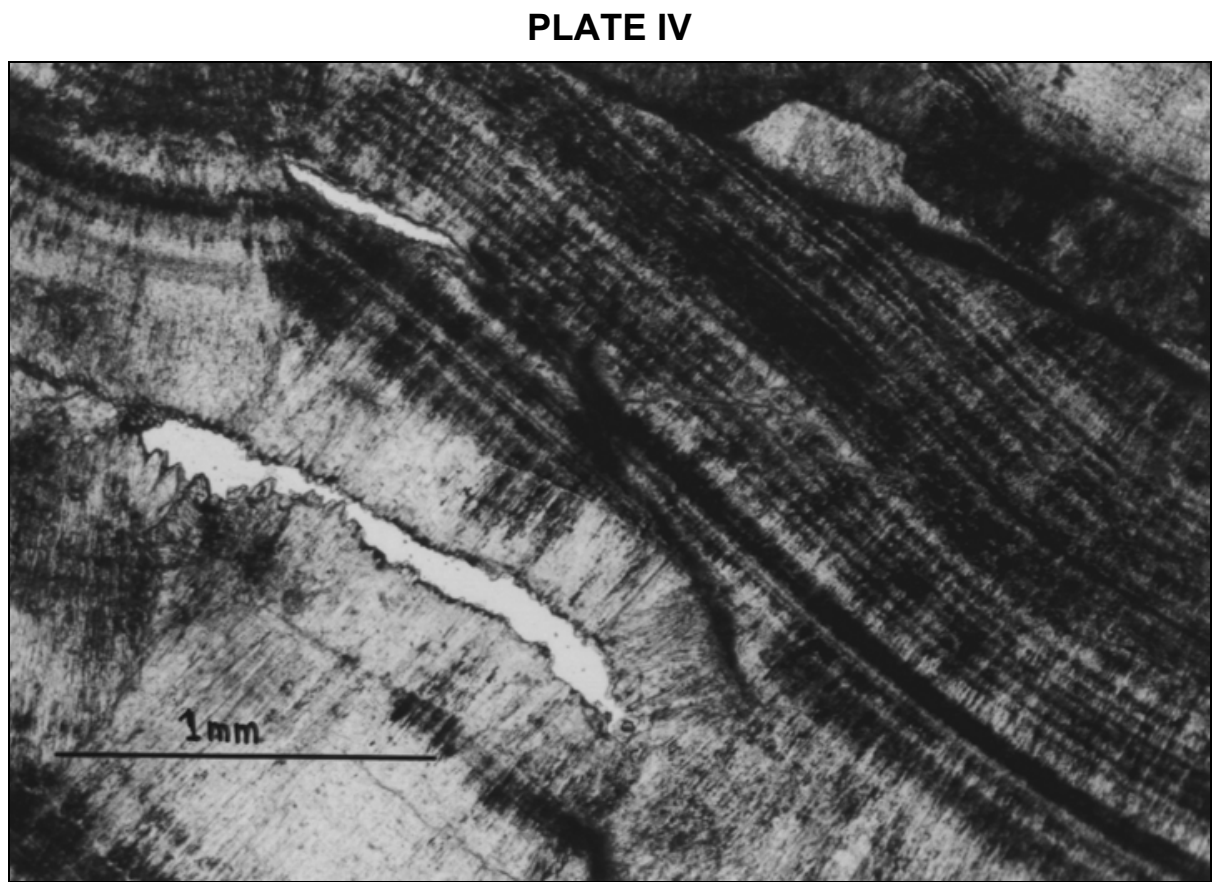

Fig. 7. Calcite paramorphosis on aragonite. The hollows are linned by small calcite crystals. $1 \mathrm{~N}, \times 40$.

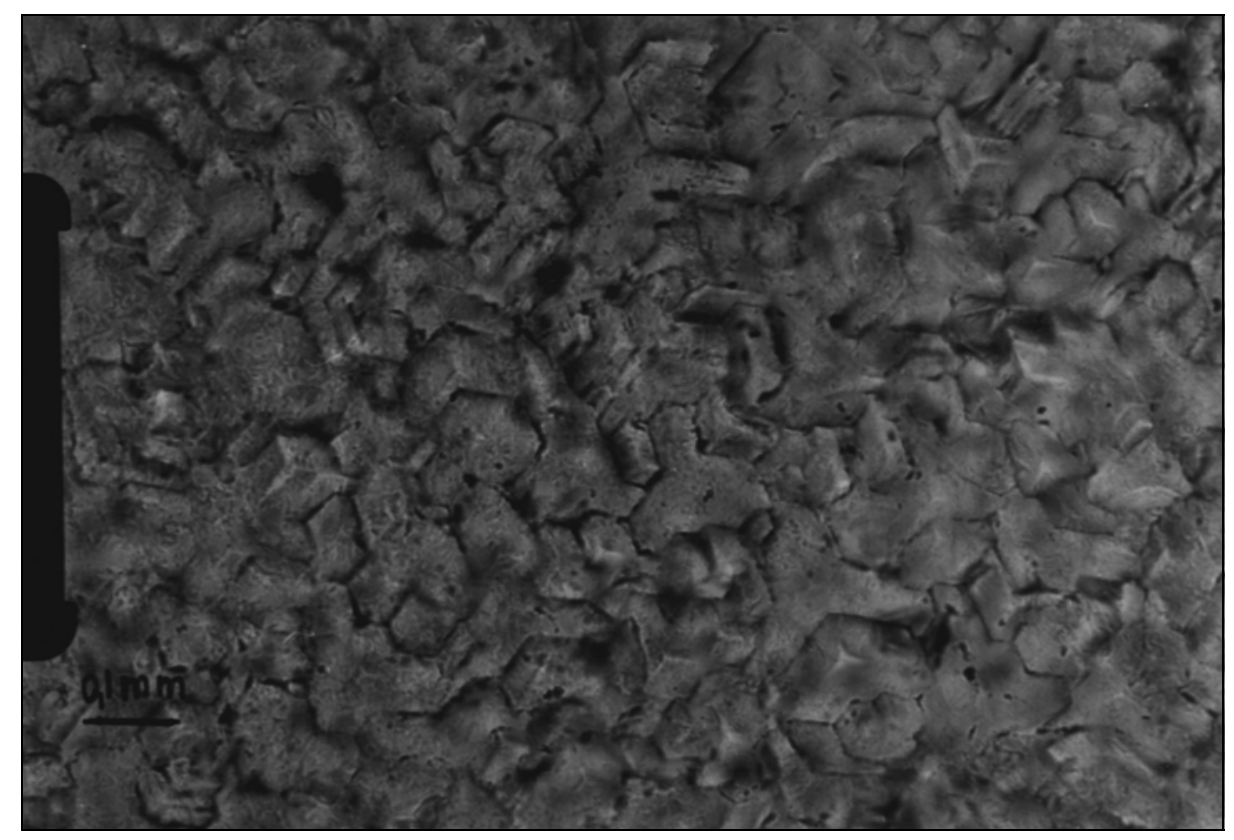

Fig. 8. Calcite paramorphosis on aragonite. $1 \mathrm{~N}, \mathrm{x} 100$. 